\title{
Reef-fish community structure and dynamics: an interaction between local and larger-scale processes?
}

\author{
M. Julian Caley* \\ Department of Marine Biology, James Cook University, Townsville, Queensland 4811, Australia
}

\begin{abstract}
Studies of coexistence in biotic communities have focused largely on local ecological processes. As a result, effects of regionally varying processes on community structure and their interactions with other processes operating locally have received considerably less attention. Here I investigate variation in predator abundance and species richness at a large spatial scale and associated community-wide patterns of species richness and abundance of tropical fishes on Australia's Great Barrier Reef. I constructed reefs from natural substrata to standardize their structure, isolation and history, which could otherwise be confounded between locations. Recruitment, both total abundance and species richness of recruits, to these reefs was greater at the northern location than at the southern one. In contrast, communities of resident fishes that developed on these reefs showed the opposite pattern; species richness and abundance were greater on the southern reefs. Piscivorous fishes were proportionately more abundant on the northern reefs. Therefore, predators were more abundant at the location with greater recruitment but lower abundance and species richness of resident fishes. Also, the declines in species richness and abundance of fishes from the observed maximum in one year to the following observed minimum were related to average predator densities among reefs. These results suggest that one ecological process that varies between distant locations, in this case predation estimated by predator abundance, may overnide the effects of other ecological processes, in this case recruitment, in determining local patterns of coexistence. Furthermore, they suggest that understanding causes of local patterns of species richness and abundance may require information about processes that determine regional variation in ecological interactions.
\end{abstract}

KEY WORDS: Community structure - Coral-reef fishes - Local processes - Predation - Recruitment . Regional processes

\section{INTRODUCTION}

Local patterns of community structure can be affected by regional patterns of species diversity in at least 2 ways. First, local species richness must be some function of regional species richness (reviews by Ricklefs 1987, Cornell \& Lawton 1992, and Cornell 1993). In the most obvious case, local species richness can not exceed regional species richness. Second, combinations of species available in a regional species pool from which a local community can be assembled may affect the outcome of local ecological interactions such

·E-mail: julian.caley@jcu.edu.au as competition and predation. Furthermore, these effects may vary among regions. It is now firmly established that local species richness can be related to regional species richness (Ricklefs 1987, Cornell \& Lawton 1992, Cody 1993, Cornell 1993, Schluter \& Ricklefs 1993, Westoby 1993). It remains to be seen, however, how differences in regional species pools affect the outcome of local ecological interactions in natural communities. Such regional differences could exert considerable influence on local community dynamics if either the amount of competition or predation faced by locally coexisting species changes as a result of changes in the composition of regional species pools. The main purpose of this paper is to investigate how regional differences in species pools, especially 
the relative abundance of piscivorous species, might affect local community dynamics and, in turn, affect geographical differences in community structure.

Communities of tropical reef fishes are among the most diverse vertebrate communities on Earth (Emery 1978) and many studies have investigated how patterns of coexistence in these communities might be determined by local ecological processes such as competition, predation, and recruitment. Debate on the relative importance of these processes continues (cf. Doherty 1991, Hixon 1991, Jones 1991). Meanwhile, regional differences among species pools and the possible importance of these differences in causing variation in local patterns of coexistence in reef-fish communities have been ignored.

Predation is one process that might vary regionally and evidence of its effects at local spatial scales has been reported for a wide variety of communities (Sih et al. 1985). Piscivorous fishes are often locally abundant and speciose on coral reefs (Goldman \& Talbot 1976, Williams \& Hatcher 1983, Hixon 1991). Furthermore, survivorship curves characterized by large losses at early ages with loss rates decreasing through time are also common in populations of reef fishes (Doherty \& Sale 1985, Victor 1986, Eckert 1987, Shulman \& Ogden 1987, Meekan 1988, Sale \& Ferrell 1988). This combination of large numbers of predators and poor survivorship of recently settled fishes constitutes circumstantial evidence (sensu Hixon 1991) of the effect of predation on the local structure and dynamics of populations and communities of tropical reef fishes. There is also direct evidence that high rates of disappearance of young fishes can be the result of predation (e.g. Sweatman 1984j. If these survivorship curves generally reflect the actions of predators, predators could alter levels of species richness and abundance set at the time of settlement or disrupt competitive interactions by reducing local densities of competitors. That predators can affect local patterns and processes in populations and communities of reef fishes has now been demonstrated in a number of experiments (Shulman et al. 1983, Doherty \& Sale 1985, Hixon \& Beets 1989, 1993, Caley 1993, Caley \& St. John in press).

While predators may affect local community dynamics, these effects may also vary regionally. For instance, regional species pools from which communities of reef fishes are drawn vary geographically both in the numbers and identities of species represented within those pools (Allen 1975, Springer 1982, Russell 1983, Myers 1989, Thresher 1991). Therefore, if either the relative species richness or relative abundance of piscivorous versus non-piscivorous species also varies regionally, the outcomes of local ecological interactions could be affected and cause regional differences in local patterns of coexistence.
Here I investigate the possibility that differences in predator abundance at geographically separate locations are related to local patterns of coexistence within communities of tropical reef fishes. Variation in predator diversity and abundance at a large spatial scale was examined by studying reef-fish communities at 2 widely separated $(>1000 \mathrm{~km}$ ) locations. For this investigation I used communities inhabiting artificial reefs (see below) rather than natural habitats. The design of these artificial reefs was identical at both locations and reefs were uninhabited by fishes at the beginning of the experiment. This design had the advantage of allowing the examination of the effects of interlocational differences in species pools on local patterns of coexistence in physically identical habitats. In this way, local patterns of coexistence could not be confounded by interlocational differences in habitat characteristics. Neither could the history of occupation of these reefs by fishes confound comparisons at large and small spatial scales.

\section{METHODS}

This study was part of a larger experiment designed to investigate the effects of disturbance on the structure of reef-fish communities (Caley 1991). The 2 study locations were on Australia's Great Barrier Reef at Lizard Island $\left(14^{\circ} 38^{\prime} \mathrm{S}, 145^{\circ} 28^{\prime} \mathrm{E}\right)$ in the north, and One Tree Island $\left(23^{\circ} 30^{\prime} \mathrm{S}, 152^{\circ} 06^{\prime} \mathrm{E}\right)$ in the south. The experiment continued from August 1987 to March 1990 at One Tree Island and from August 1988 to April 1990 at Lizard Island.

At both locations, the experiment began during winter with the construction of experimental reefs. Reefs were built from dead coral rubble using a modular design. Rubble was collected from emergent reef crest and shallow subtidal areas. I built each reef using approximately $0.8 \mathrm{~m}^{3}$ of rubble placed in 2 to $5 \mathrm{~m}$ of water (low tide). Each reef was separated from all others by at least $20 \mathrm{~m}$ of open sand. Reefs were isolated in this way to reduce movement of fishes among reefs and fishes observed to move among reefs were removed from analyses (see below).

The rubble for each reef was arranged in 7 piles each approximately $0.5 \mathrm{~m}$ in height and diameter. The 7 piles were arranged with 1 at the center surrounded by a ring of 6 others. Each rubble pile was approximately $1 \mathrm{~m}$ from its nearest neighbor, and the total diameter of each reef was approximately 3 to $5 \mathrm{~m}$. These experimental reefs were maintained on a regular basis by restacking any rubble that became dislodged from the piles.

Reefs at both locations (i.e. Lizard Island and One Tree Island) were built at 2 separate sites. Sites within 
locations were separated by 0.5 to $1 \mathrm{~km}$ and 15 reefs were built at each site. Communities of fishes on these reefs assembled and were maintained by natural processes of recruitment and were subject to unmanipulated levels of predation. Three reefs within each site were randomly assigned to one of 4 disturbance treatments and an undisturbed control treatment. Disturbance of these communities involved the removal of fishes from subsets of rubble piles within reefs. The effects of both intensity (i.e. number of rubble piles denuded of fish) and frequency (i.e. rubble piles denuded of fish once or twice per year) of disturbance were investigated. Disturbance manipulations did not interact consistently with patterns of recruitment or residency at the levels of sites and locations (Caley 1991). Because interlocational comparisons of species richness and abundance are the subject of this paper, and because interlocational patterns did not interact with disturbance manipulations, the patterns of community structure reported here are most likely robust to the effects of these disturbances.

During this experiment, I visited each location 3 times per year: early and late summer and winter. I was unable to monitor and maintain this experiment simultaneously at both locations. Therefore, I alternated the order in which I visited each location. At the beginning of each visit to a location I counted all fish present on each experimental reef at each site. Following this initial census during early and late summer, I also applied prescribed experimental disturbances. Except for the first visit to each location during the first year, I censused each reef again following the experimental disturbances. Therefore, fishes were censused 4 times in the first year at each location and 5 times per year during the rest of the experiment.

Census techniques. Censuses were done during periods of greatest subtidal visibility. If visibility decreased sufficiently to make fish counting difficult, counting ceased until visibility improved. I censused each reef in 2 steps. First, I counted fish from as far away from a reef as possible to allow those species that used the water column above the reef to be counted while undisturbed. Second, to count fish sheltering in the interstices of a reef I approached the reef and counted fish by closely examining each rubble pile in turn. During both steps of each census all fish were counted and assigned to size categories based on visual estimates of total length (TL). Fish were placed in $10 \mathrm{~mm}$ size classes from 0 to $100 \mathrm{~mm}, 25 \mathrm{~mm}$ size classes from 100 to $200 \mathrm{~mm}$ and $100 \mathrm{~mm}$ size classes above $200 \mathrm{~mm}$. Each count continued until no new species could be found and the abundance of each species was similar between successive counts for that species. Generally, the census of a reef took between 20 and 40 min to complete.
Fishes counted on these reefs were classified as recruits, residents or transients and as piscivores or non-piscivores. Fish were deemed to be newly settled recruits if I estimated them to be within the smallest $10 \mathrm{~mm}$ size class (TL) observed for that species. Minimum size classes used for categorizing individuals of each species as recruits were established in the following way. Individuals newly settled from the plankton have little pigmentation compared to other fishes that have been settled longer The estimated size of these fishes was used to establish the minimum size class for recruits. I then checked my ability to estimate this size-class underwater by using individuals I removed during disturbances (author's unpubl. data).

Abundance of recruits of all species of fishes could not be estimated reliably. For most such species, nonpigmented individuals were never observed. Presumably, this was because individuals of these species either pigment quickly after settling or are cryptic until after they have pigmented. In addition, the maximum size of one species of fish, Eviota sp. (Gobiidae), was too small for individuals in the smallest $10 \mathrm{~mm}$ size class to be meaningfully called recruits, and a few species were sufficiently cryptic to prevent reliable counts of recruits of those species. It was possible, however, to count recruits of the majority of fish species that colonized these reefs (Table 1). Only those species for which recruits could be reliably counted were included in estimates of recruitment. Because recruitment was measured relatively infrequently, estimates of recruitment in this study confound patterns of settlement plus any mortality between settlement and the next census

Fishes estimated to be larger than the maximum size for recruits of a particular species were classified as either residents or transients. Residents were those fishes that appeared to inhabit individual reefs whereas transients were those fishes that were known to move among reefs. For some species, particularly wrasses (Labridae), individuals tended to become transient as they reached larger size classes. Throughout the analyses below, recruits and residents have been analyzed separately, and transients have been excluded.

Species of fish were categorized as being either piscivorous or non-piscivorous using a combination of published accounts of diets (e.g. Hiatt \& Strasburg 1960. Randall et al. 1990, Sweatman 1993) and personal observations of piscivory by individuals of these species. Below, I refer to individuals of piscivorous species as predators. The size criteria used to categorize individual fish as recruit, resident or transient and decisions made regarding the piscivorous or nonpiscivorous nature of each species are presented in Table 1 
Table 1. Species of fishes encountered during censuses and/or removed from artificial reefs at Lizard Island and One Tree Island Species are listed alphabetically by Family following the systematics of Randall et al. (1990) for placing species within families The size criteria (total length: TL) used to classify fish as recruits and transients are provided. For all species with a total abundance greater than 10, estimates of mean abundance and SE per reef for the first 4 censuses at each location are provided. + : species that were censused during the first 4 censuses whose total abundance at a particular location was 10 or fewer. -: species that were present on these reefs during the second and third year of the experiment but not the first, or that were removed during experimental disturbances at any time during this study but were not observed during censuses. (p): a species that was deemed to be piscivorous

\begin{tabular}{|c|c|c|c|c|c|c|c|c|c|}
\hline $\begin{array}{l}\text { Famuly } \\
\text { Genus species }\end{array}$ & $\begin{array}{l}\text { Max. } \\
\text { size of } \\
\text { recruits } \\
\text { (mm } T L)\end{array}$ & $\begin{array}{l}\text { Min. } \\
\text { slze of } \\
\text { transients } \\
\text { (mm TI.) }\end{array}$ & $\begin{array}{l}\text { Lizard } \\
\text { Island } \\
\bar{x} \text { (SE) }\end{array}$ & $\begin{array}{l}\text { One } \\
\text { Tree } \\
\text { Island } \\
\tilde{x}(S E)\end{array}$ & $\begin{array}{l}\text { Family } \\
\quad \text { Genus species }\end{array}$ & $\begin{array}{l}\text { Max. } \\
\text { size of } \\
\text { recruits } \\
\text { (mm TL) }\end{array}$ & $\begin{array}{l}\text { Min. } \\
\text { size of } \\
\text { transients } \\
\text { (mm TL) }\end{array}$ & $\begin{array}{c}\text { Lizard } \\
\text { Island } \\
\vec{X}(\mathrm{SE})\end{array}$ & $\begin{array}{c}\text { One } \\
\text { Tree } \\
\text { [sland } \\
\bar{x}(\mathrm{SE})\end{array}$ \\
\hline \multicolumn{5}{|l|}{ Acanthoclinidae: } & \multicolumn{5}{|l|}{ Cirrhitidae: } \\
\hline Belonepterygion fasciolatum & & & - & + & Paracirrhites sp. $1(\mathrm{p})$ & & & - & \\
\hline Acanthuridae: & & & & & Gobiesocidae: & & & & \\
\hline Acanthurus spp. juv. & 45 & 150 & $2.3(2.4)$ & $0.1(0.3)$ & Diademichthys sp. 1 & & & - & + \\
\hline Ctenochaetus striatus & & & + & & Gobiidae: & & & & \\
\hline Naso annulatus & 45 & 150 & $0.3(0.7)$ & $0.1(0.4)$ & Amblygobius decussatus & & & & $0.2(0.7)$ \\
\hline Naso brevirostns & 45 & 150 & & - & Amblygobius phalaena & 25 & & $8.5(9.1)$ & 11.219 .1 \\
\hline Antennariidae: & & & & & Asterropteryx semipunctatus & 25 & & $2.1(2.6)$ & $25.7(19)$ \\
\hline Antennarius coccineus (p) & & & & - & Callogobuus sp. 1 & 25 & & - & - \\
\hline Apogonidae: & & & & & Cryptocentrus cinctus & & & & + \\
\hline Apogon compressus & 25 & & - & - & Eviotasp. 1 & & & - & - \\
\hline Apogon cyanosoma & 25 & & + & + & Fusigobius neophytus & 25 & & - & - \\
\hline Apogon doederlem & 25 & & $12\{43\}$ & $77.7(82)$ & Istigobius decoratus & 25 & & - & $0.3(0.6)$ \\
\hline Apogon exostigma & 25 & & & - & Istigobius roglius & 25 & & - & + \\
\hline Apogon fragilis & 25 & & + & $35.2(65)$ & Oplopomus oplopomus & 25 & & & + \\
\hline Apogon guamensis & 25 & & $0.1(0.4)$ & & Priolepss cincta & & & - & - \\
\hline Apogon sp. 1 & 25 & & $0.8(4.4)$ & + & Valenciennea longipinnis & 25 & & $0.3(0.7)$ & $3.5(4.1)$ \\
\hline Apogon sp. 2 & & & $t$ & + & Valenciennea sp. 1 & & & - & - \\
\hline Archamia leal & us 25 & & $\stackrel{t}{t} 11$ & $7 . \overline{1} 9.31$ & Yongeichthys nebulosus & 25 & & - & $2.9(3.1)$ \\
\hline $\begin{array}{l}\text { Cheilodipterus quinquelineatus } \\
\text { Fowlerra abocellata }\end{array}$ & US $\begin{array}{ll}20 \\
25\end{array}$ & & $1.1(3.1)$ & $\begin{array}{c}1.1(9.3) \\
-\end{array}$ & Haemulidae: & & & & \\
\hline Fowleria variegata & 25 & & - & + & Diagramma pictum & 50 & & $0.1(0.5)$ & + \\
\hline Balistidae: & & & & & Hemiscyllidae: & & & & \\
\hline Pseudobalistes flavimarginatus & us 45 & & $0.5(0.8)$ & + & Chiloscyllium punctatum (p) & & & & + \\
\hline Pseudobalistes fuscus & 45 & & + & - & Holocentridae: & & & & \\
\hline Rhinecanthus aculeatus & 35 & 150 & $0.5(0.7)$ & + & Neoniphon sammara & 25 & & $0.4(0.8)$ & \\
\hline Sufflamen chrysopterus & & & $0.1(0.4)$ & & Sargocentron sp. 1 & & & + & \\
\hline Batrachoididae: & & & & & Labridae: & & & & \\
\hline Halophryne diemensis (p) & 25 & & - & - & Chellnus chlorourus & 25 & & + & + \\
\hline Blenniidae: & & & & & Chellinus dragrammus & & & & - \\
\hline Aspidontus dussumieri & & & - & - & Cirrhilabrus punctatus & 25 & & & $0.5(0.8)$ \\
\hline Atrosalarias fuscus & 25 & & - & - & Cons dorsomacula & & & & + \\
\hline Ecsenius bicolor & & & - & - & Cons pictoides & & & & + \\
\hline Ecsenius mandibularis & 25 & & - & $0.7\{1.1\}$ & Coris schroederi & 25 & & $1.7(1.8)$ & $0.3(0.6)$ \\
\hline Meiacanthus grammistes & 25 & & $0.4(0.7)$ & - & Cymolutes praetexiatus & & & $1.7(1.7)$ & $0.3(0.7)$ \\
\hline Meiacanthus lineatus & 25 & & & $0.1(0.4)$ & Haluchoeres chloropterus & 25 & & + & \\
\hline Petroscirtes fallax & 25 & & + & $1.1(1.3)$ & Hahchoeres melanurus & 25 & & $0.1(0.4)$ & \\
\hline Petroscirtes lupus & & & - & $2.7(3.1)$ & Halichoeres nebulosus & 25 & & + & + \\
\hline Petroscirtes mitratus & 25 & & $1.7(2.2)$ & $2.5(1.9)$ & Halichoeres trimaculatus & 25 & 150 & + & $0.6(1.8)$ \\
\hline Petroscirtes xestus & 25 & & - & & Hemigymnus melapterus & 25 & & + & + \\
\hline Plagiotremus rhinorhynchos & & & + & - & Labrichthys unilineatus & & & & - \\
\hline Plagiotremus tapeinosoma & & & - & & Labroides dimidiatus & 25 & & - & + \\
\hline Salarias fasciatus & 25 & & & + & Leptolulis cyanopleura & 25 & & & $0.2(0.5)$ \\
\hline Salanas sp. 1 & 25 & & $0.5\{1.1\}$ & - & Macropharyngodon negrosenst & & & & - \\
\hline Stanulus sp. 1 & 25 & & - & & Stethojuls bandanensis & & 125 & - & \\
\hline Bythitidae: & & & & & Stethojulis strigiventer & 25 & 125 & $0.8(1.3)$ & + \\
\hline Dinematichthys sp. 1 & & & - & - & Thalassoma hardwicke & & 125 & & - \\
\hline $\begin{array}{l}\text { Caesionidae: } \\
\text { Caesiosp. I juv. }\end{array}$ & & & + & & Thalassoma lunare & 25 & 125 & + & $0.2(1.4)$ \\
\hline Carangidae. & & & & & Lethrinıdae: & & & & \\
\hline Caranx sp. 1 juv. & & & - & & Lethrinus nebulosus ( $p$ ) & 45 & 150 & $0.6(1.4)$ & $0.2(0.5)$ \\
\hline Centriscidae: & & & & & $\begin{array}{l}\text { Lutjanidae: } \\
\text { Lutjanus carponotatus (p) }\end{array}$ & 35 & 100 & - & \\
\hline $\begin{array}{l}\text { Aeoliscus stngatus } \\
\text { Chaetodontidae: }\end{array}$ & 25 & & + & & Lutjanus fulvilamma (p) & 35 & 100 & - & \\
\hline Chaetodontidae: & 35 & 150 & $0.3(0.7)$ & + & Lutjanus gibbus $(\mathrm{p})$ & 35 & 100 & $1.3(2.1)$ & + \\
\hline Chaetodon ephippium & $\begin{array}{l}30 \\
35\end{array}$ & & $\begin{array}{c}0.010 .9 \\
+\end{array}$ & & Lutjanus kasmira $(\mathrm{p})$ & 35 & 100 & $7.8(15)$ & - \\
\hline Chaetodon flavrostris & 35 & & & - & Lutjanus lutjanus $(\mathrm{p})$ & 35 & 100 & + & \\
\hline Chaetodon kleinis & 35 & & + & & Lutjanus quinquelineatus (p) & 35 & 100 & + & \\
\hline Chelmon rostratus & 35 & 150 & & $0.1(0.4)$ & Microdesmidae: & & & & \\
\hline Heniochus acuminatus & & & + & & Ptereleotris microlepus & & & $0.8(3.1)$ & $1.1(2.8)$ \\
\hline
\end{tabular}


Table 1 (continued)

\begin{tabular}{|c|c|c|c|c|c|c|c|c|c|}
\hline $\begin{array}{l}\text { Famuly } \\
\text { Genus species }\end{array}$ & $\begin{array}{l}\text { Max. } \\
\text { size of } \\
\text { recruits } \\
\text { (mm TL) }\end{array}$ & $\begin{array}{c}\text { Min. } \\
\text { size of } \\
\text { transients } \\
\text { (mm TL) }\end{array}$ & $\begin{array}{l}\text { Lizard } \\
\text { Island } \\
\bar{x}(\mathrm{SE})\end{array}$ & $\begin{array}{c}\text { One } \\
\text { Tree } \\
\text { Island } \\
\bar{x} \text { (SE) }\end{array}$ & $\begin{array}{l}\text { Family } \\
\text { Genus species }\end{array}$ & $\begin{array}{l}\text { Max. } \\
\text { size of } \\
\text { recruits } \\
\text { (mm TL) }\end{array}$ & $\begin{array}{l}\text { Min. } \\
\text { size of } \\
\text { transients } \\
\text { (mm TL) }\end{array}$ & $\begin{array}{l}\text { Lizard } \\
\text { Island } \\
\bar{x}(S E)\end{array}$ & $\begin{array}{c}\text { One } \\
\text { Tree } \\
\text { Island } \\
\bar{x} \text { (SE) }\end{array}$ \\
\hline Monacanthidae: & & & & & Pomacentrus chrysurus & 25 & & $1.6(2.4)$ & $0.2(0.5)$ \\
\hline Acreichthys radialus & 25 & & - & - & Pomacentrus grammorhynchus & 25 & & - & \\
\hline Paraluteres prionurus & & & & - & Pomacentrus nagasakiensis & 25 & & $7.4(8.2)$ & $0.3(0.9)$ \\
\hline Pervagor janthinosoma & & & & - & Pomacentrus pavo & 25 & & $0.6(1.1)$ & $0.1(0.4)$ \\
\hline Mullıdae: & & & & & Pomacentrus trpunctatus & 25 & & + & \\
\hline Mulloides flavolineatus & 45 & 100 & + & - & Pomacentrus wardi & 25 & & $0.9(1.7)$ & $0.2(0.4)$ \\
\hline Parupeneus barberinus & 45 & 100 & $0.3(0.8)$ & - & Pseudochromidae: & & & & \\
\hline Parupeneus ciliatus & & 100 & + & - & Congrogadus subducens (p) & 25 & & & - \\
\hline Parupeneus multufasciatus & & 100 & - & & Ogilbyina queenslandiae $(p)$ & 25 & & $0.4(0.9)$ & $1.2(1.4)$ \\
\hline Parupeneus pleurostigma & 45 & 100 & $0.2(0.4)$ & & Pseudochromis fuscus $(\mathrm{p})$ & 25 & & $1.8(1.5)$ & + \\
\hline Upeneus tragula & 45 & 100 & & + & Scaridae: & & & & \\
\hline Muraenidae: & & & & & Scarus sordidus & & & & + \\
\hline Gymnothorax chilospilus (p) & & & - & & Scarus spp. juv. & 25 & & $1.8(3.4)$ & $2.4(2.2)$ \\
\hline Gymnothorax sp. 1 (p) & & & & + & Scorpaenidae: & & & & \\
\hline Nemipteridae: & & & & & Dendrochirus brachypterus (p) & 35 & & & + \\
\hline Pentapodus sp. 1 & & & + & & Dendrochirus zebra $(\mathrm{p})$ & 35 & & + & + \\
\hline Scolopsss bilineatus & 35 & & - & + & Scorpaenodes guamensis (p) & 35 & & + & + \\
\hline Scolopsis lineatus & & & & - & Scorpaenopsis diabolus $(\mathrm{p})$ & & & & - \\
\hline Scolopsis monogramma & 35 & & $3.0(5.7)$ & - & Serranidae: & & & & \\
\hline Ophichthidae: & & & & & Cephalopholis boenak $(\mathrm{p})$ & 35 & & + & \\
\hline Muraenichthys sp. 1 & & & - & & Cromileptes altivelis $(\mathrm{p})$ & 35 & & - & \\
\hline Ostraciidae: & & & & & Epinephelus cyanopodus (p) & 35 & & - & \\
\hline Ostracion cubicus & 25 & 150 & & + & Epinephelus maculatus (p) & 35 & & + & \\
\hline $\begin{array}{l}\text { Pinguipedidae: } \\
\text { Parapercis cylindrica }\end{array}$ & 25 & & $1.3(1.6)$ & $3.6(2.9)$ & Epinephelus quoyanus (p) & 35 & & + & - \\
\hline Parapercis hexophtalma & 25 & & & + & Grammistes sexlineatus $(\mathrm{p})$ & & & - & \\
\hline Parapercis sp. 1 & & & & _ & Plectropomus leopardus (p) & 35 & & - & - \\
\hline Platycephalidae: & & & & & Siganıdae: & & & & \\
\hline Thysanophryssp. 1 (p) & 25 & & - & - & Siganus doliatus & & 150 & + & - \\
\hline Plesiopidae: & & & & & Siganus punctatus & & 150 & - & \\
\hline Paraplesiops powen & & & & - & Sigãnus spp. juv & 25 & & + & \\
\hline Pomacanthidae: & & & & & Solenostomidae: & & & & \\
\hline Centropyge tibicen & 35 & & & + & Solenostomus paradoxus & & & - & \\
\hline Pomacentridae: & & & & & Syngnathidae: & & & & \\
\hline Abudefduf sexfasciatus & & & & - & Choeroichthys sculptus & 25 & & - & - \\
\hline Acanthochromis polyacanthus & 25 & & & $5.8(9.6)$ & Corytholchthys intestinalis & 25 & & + & + \\
\hline Amblypomacentrus breviceps & 25 & & + & & Doryrhamphus excisus & 25 & & - & - \\
\hline Chromis nitida & 25 & & & $0.9(3.2)$ & Synodontidae: & & & & \\
\hline Chrysiptera biocellata & 25 & & + & - & Synodus dermatogenys $(\mathrm{p})$ & 25 & & $0.8(1.0)$ & - \\
\hline Chrysiptera flavipinnis & 25 & & + & + & Synodus variegatus $(\mathrm{p})$ & 25 & & - & - \\
\hline Chrysiptera rex & 25 & & + & & Tetraodontidae: & & & & \\
\hline Chrysiptera rollandi & 25 & & + & & Arothron hispidus & & 150 & - & + \\
\hline Dascyllus aruanus & 25 & & - & $0.2(0.7)$ & Arothron manilensis & & 150 & + & \\
\hline Dischistodus perspicillatus & 25 & & $11.4(14)$ & $0.1(0.3)$ & Canthigaster bennetti & 25 & & $2.0(4.7)$ & + \\
\hline Dischistodus prosopotaenia & 25 & & $0.1(0.4)$ & + & Canthigaster solandri & 25 & & + & \\
\hline Neoglyphidodon melas & 25 & & + & & Canthigaster valentini & 25 & & + & $0.1(0.3)$ \\
\hline Neopomacentrus azysron & 25 & & - & & Trichonotıdae: & & & & \\
\hline Pomacentrus amboinensis & 25 & & $10.4(12)$ & $1.1(1.4)$ & Trichonotus sp. 1 & & & - & \\
\hline Pomacentrus australis & & & & - & Tripterygiidae: & & & & \\
\hline Pomacentrus bankanensis & 25 & & + & & Ennaepterygius sp. 1 & & & - & \\
\hline
\end{tabular}

Patterns of recruitment and community composition. I compared the average species richness and abundance of fishes newly recruited to reefs at Lizard Island and One Tree Island using census data from each location. In the second year of the study, the experiment ended before a noticeable seasonal decline in abundance had begun at Lizard Island following summer recruitment. Therefore, interlocational comparisons were only made using data from the first year at each location. This was done to avoid comparing maximum recruitment levels where I could not be sure that recruitment had indeed peaked. Because recruitment of fishes at these locations can be extremely patchy (Caley \& St. John in press), average values of species richness and abundance of recruits were calculated for each reef from the 3 censuses that spanned the summer recruitment season. Interlocational comparisons were then made using these reef means (i.e. for each location: 15 reefs $\times 2$ sites). 
I investigated whether interlocational patterns of community composition of resident fishes reflected differences in patterns of recruitment at these locations. To do so, the species richness and abundance of resident fishes at Lizard Island and One Tree Island following the end of recruitment in the first year of the experiment and before the onset of recruitment in the second year were compared. Here estimates of resident abundance and species richness from the winter census at each location were used. All interlocational comparisons of estimates of species richness and abundance of recruit and resident fishes were made using ANOVA. Location was analyzed as a fixed effect and site as a random effect nested within locations. Intensity and frequency of disturbance were analyzed as fixed effects and the control treatment was analyzed as a factor asymmetrical to the disturbance treatments (Winer 1971). Variances were tested for homogeneity using Cochran's test. Where variances were heteroscedastic, data were $\log (x+1)$ transformed and variances were retested for homogeneity following transformation. In all cases this transformation homogenized variances.

Effects of predators. If predators influence patterns of coexistence in a particular community, their effects may be related to their relative abundance within that community. Therefore, I compared the percentage abundance of predators in the fish communities at the 2 locations. Furthermore, if predators influence the dynamics of communities, the dynamics of predators may differ from those of the community as a whole. For instance, while predator abundance might be expected to decline through time, losses of predators might be less than losses from the general community. Therefore, I compared patterns of recruitment of predators between locations and examined how patterns of residency of predators were related to their patterns of recruitment. These analyses were done using the ANOVA design described above, but calculated for piscivorous fishes only. In addition, using a $2 \times 2$ contingency table analysis I examined whether species richness of predators relative to non-predator species differed between locations.

Finally, I examined whether the magnitude of seasonal declines in species richness and abundance of the total fish communities were related to predator densities. The removal of fishes from reefs during experimental disturbances, however, could confound effects of predators on community structure. Therefore, in this analysis I only used data collected from control reefs, those that I did not disturb throughout the experiment. Using these data I compared the percentage change in species richness and total abundance of resident non-piscivorous fishes from the maximum reached during the summer of the first year to the following winter as a function of average predator abundance. Percentage change was used to standardize differences in average species richness and abundance among reefs. Predator abundances, the mean number of predators with recruits and residents combined counted on a particular reef over the same period, were calculated separately for each reef.

The relationships between predator abundance and the abundance and species richness of resident fishes were described using ANCOVA and linear regression. ANCOVA was used to test for locational effects and for interactions between location and mean predator abundance. Where interlocational effects and interactions were not detected $(p>0.25)$, these factors were pooled and the relationships between mean predator abundance and the change in abundance and species richness of the total community were examined using linear regression. These analyses used percentage change as the dependent variable. Therefore, I examined whether these relationships between predator abundance and percent change in total abundance and species richness were likely to be affected by nonnormal distributions of percentage values. I did this in 2 ways. First, I examined normal probability plots for severe deviations from normality. Second, I repeated the above regression analyses using arcsine transformed data. No severe deviations from normality were detected using normal-probability plots and arcsine transformation did not affect the results of the regression analyses. Therefore, only analyses of the non-transformed data are presented below.

\section{RESULTS}

\section{Community structure}

Recruits of 119 species of fish were censused on these experimental reefs, or removed from them during experimental disturbances. Of these, 95 and 76 species were present on the reefs at Lizard Island and One Tree Island, respectively. Residents of 166 species of fish were censused on these reefs, or removed from them during disturbances. Of these, 124 and 126 species were present on the reefs at Lizard Island and One Tree Island, respectively. Species richness of piscivorous fishes at Lizard Island (24 species) was slightly greater than at One Tree Island (19 species). The number of species of predators relative to the number of species of non-predators, however, did not differ between locations $(2 \times 2$ contingency table: $G=$ $0.29, p>0.55)$. Identities of the species of fishes encountered at these 2 locations, and their deemed status as either piscivores or non-piscivores, are presented in Table 1. 


\section{Community dynamics}

Because the factor location was fixed, comparisons between locations, with only 1,2 df, were among the least powerful in this experimental design. Despite the lack of power in these comparisons, differences in the dynamics of these fish communities between locations were statistically significant. For instance, average species richness and abundance of newly recruited fishes were greater on reefs at Lizard Island (Table 2). Greater recruitment at Lizard Island, however, did not translate into greater species richness and abundance of resident fishes on these reefs. Patterns of species richness and abundance of resident and recruit fishes were reversed at the 2 locations. Both minimum species richness and minimum abundance of resident fishes, following one season of recruitment and before the onset of the next, were less on the reefs at Lizard Island (Table 2).

\section{Dynamics of predators and their effects}

The relative abundance of predators on the Lizard Island reefs was consistently greater than on the One Tree Island reefs by more than an order of magnitude (mean percentage abundance of predators: Lizard Island $=10.6 \%$, One Tree Island $=0.7 \% ; \mathrm{n}=60$ reefs, $F_{1,2}=148, \mathrm{p}<0.01$ ). At Lizard Island, the location with the greater abundance of piscivorous fishes, both abundance and species richness of recruiting fishes began higher, yet abundance and species richness of residents ended lower than at One Tree Island. The dynamics of the predator communities on these reefs, in contrast, differed from the dynamics of the communities as a whole. Patterns of recruitment of predators paralleled the patterns of recruitment for the entire community with greater abundance and species richness of recruits at Lizard Island compared to One Tree Island. While patterns of species richness and abundance of resident fishes of all species were reversed at the 2 locations, patterns for predators were not (Table 2). Therefore, interlocational differences in the dynamics of the whole community compared with predators alone were consistent with a regionally varying effect of predators on local patterns of coexistence.

The magnitude of the declines in abundance and species richness were unrelated to either location (ANCOVA: abundance, $F_{1.8}=0.48, \mathrm{p}>0.47_{i}$ species richness, $F_{1,7}=1, \mathrm{p}>0.35$ ) or interactions between location and mean predator abundance (ANCOVA: abundance, $F_{1,8}=0.37, \mathrm{p}>0.55 ;$ species richness, $F_{1,7}$ $=0.19, p>0.67)$. Therefore, location and the location by predator abundance interaction were pooled and the relationships between predator abundance and the change in abundance and species richness across all species were examined using these pooled data.

The magnitude of the decline in abundance of resident fishes within communities was inversely related to the mean number of piscivorous fishes. Mean abundance of piscivores explained more than $50 \%$ of the variation in the decline in total abundance from maxi-

Table 2. Comparisons of the average species richness and abundance of newly recruited fishes to reefs at Lizard Island and One Tree Island and the observed minimum species richness and abundance of resident fishes reached following recruitment in the first year of the study but before the onset of recruitment in the second. Separate analyses are reported for all species and piscivorous species. Censuses of recruit abundance and species richness estimate the instantaneous rate of recruitment, whereas estimates of resident abundance and species richness sum the effects of recruitment over time plus postrecruitment mortality (see 'Methods' section for more detail). Therefore, estimates of the abundance and species richness of recruits can be less than estimates of minimum species richness and abundance of residents. Comparisons between locations were of primary interest in this study and for simplicity are the only comparisons reported here. p-values from ANOVA (1,2 df) with location (i.e. Lizard Island vs One Tree Island) analysed as a fixed effect and sites within locations analysed as a random effect. - Data transformed to $\log (x+1)$. Table values of means and SEs are presented for non-transformed data

\begin{tabular}{|c|c|c|c|c|c|c|c|c|}
\hline & & & \multicolumn{3}{|c|}{ Species richness (no. of species reef ${ }^{-1}$ ) } & \multicolumn{3}{|c|}{ Total abundance (ind. reef $f^{-1}$ ) } \\
\hline & & & $\begin{array}{l}\text { Lizard } \\
\text { Island }\end{array}$ & $\begin{array}{l}\text { One Tree } \\
\text { Island }\end{array}$ & $\mathrm{p}<$ & $\begin{array}{l}\text { Lizard } \\
\text { Island }\end{array}$ & $\begin{array}{l}\text { One Tree } \\
\text { Island }\end{array}$ & $p<$ \\
\hline \multirow[t]{2}{*}{ All species } & Recruits & $\begin{array}{l}\text { Mean } \\
\text { SE }\end{array}$ & $\begin{array}{l}6.3 \\
1.2\end{array}$ & $\begin{array}{l}2.7 \\
1.0\end{array}$ & 0.005 & $\begin{array}{r}27.8 \\
8.7\end{array}$ & $\begin{array}{r}11.9 \\
7.7\end{array}$ & $0.025^{\circ}$ \\
\hline & Residents & $\begin{array}{l}\text { Mean } \\
\text { SE }\end{array}$ & $\begin{array}{l}9.5 \\
2.4\end{array}$ & $\begin{array}{r}16.5 \\
3.3\end{array}$ & 0.01 & $\begin{array}{r}23.3 \\
5.7\end{array}$ & $\begin{array}{l}90.6 \\
20.3\end{array}$ & $0.001^{\circ}$ \\
\hline \multirow[t]{2}{*}{ Predators only } & Recruits & $\begin{array}{l}\text { Mean } \\
\text { SE }\end{array}$ & $\begin{array}{l}1.7 \\
1.0\end{array}$ & $\begin{array}{l}0.07 \\
0.2\end{array}$ & 0.002 & $\begin{array}{l}3.9 \\
3.7\end{array}$ & $\begin{array}{l}0.1 \\
0.5\end{array}$ & 0.001 \\
\hline & Residents & $\begin{array}{l}\text { Mean } \\
\text { SE }\end{array}$ & $\begin{array}{l}1.2 \\
1.0\end{array}$ & $\begin{array}{l}1.1 \\
1.0\end{array}$ & 0.15 & $\begin{array}{l}1.6 \\
1.3\end{array}$ & $\begin{array}{l}1.2 \\
1.3\end{array}$ & $0.04^{\circ}$ \\
\hline
\end{tabular}




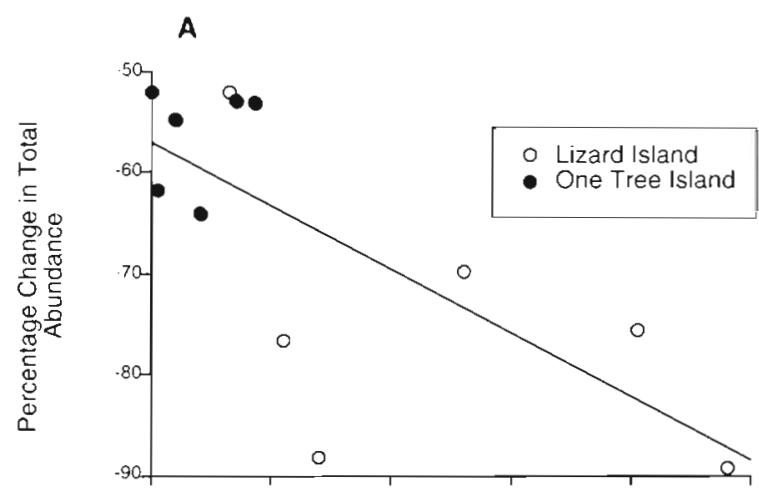

B

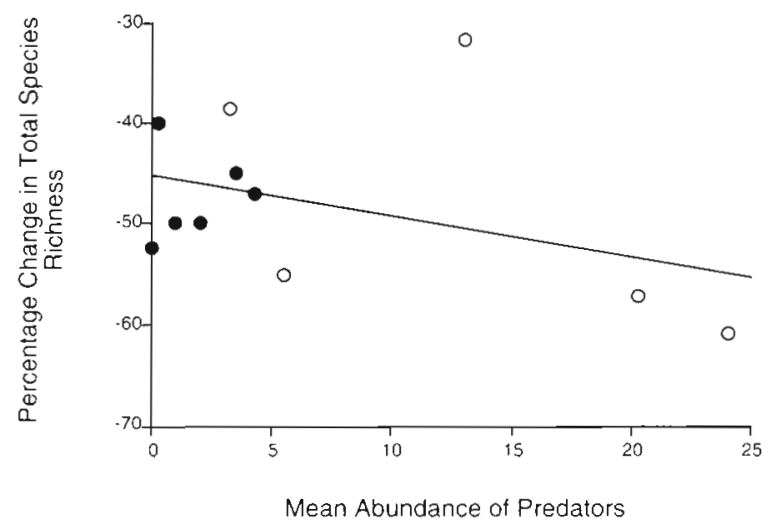

Fig. 1. Relationships between percentage change in (A) total abundance and $(\mathrm{B})$ total species richness of resident nonpiscivorous fishes on undisturbed control reefs from the maximum density observed for each reef during the first year at each location to the minimum density observed during the following winter, as a function of mean predator abundance during the same period (curves fitted using least-squares regression)

mum number of recruits to minimum number of residents across regions ( $n=12$ control reefs, slope $=-1.3$, $\mathrm{R}^{2}=0.51, \mathrm{p}<0.01 ;$ Fig. 1A). In spite of the interlocational association between predator abundance and decline in species richness, mean abundance of piscivores explained only $16 \%$ of the variation in this decline $(n=11$ control reefs 11 outlier removed; Grubbs' test, $p<0.01$ (Sokal \& Rohlf 1981)], slope = $-0.004, R^{2}=0.16, p<0.22$; Fig. 1B). Although this relationship was negative, it was not statistically significant. Therefore, these data do not describe well the exact relationship between predator abundance and decline in species richness that was evident from the interlocational comparisons. While the loss of individual fishes increased with predator abundance, the rate at which species were driven locally extinct was not a simple function of predator abundance. In total, however, these data strongly suggest that differences in patterns of local abundance and species richness were related to an interaction between locational differences in the relative abundance of piscivores and the effects of these differences on local ecological interactions and the resulting composition of local communities.

\section{DISCUSSION}

High percentage representation of piscivorous fishes in communities of coral-reef fishes (Goldman \& Talbot 1976, Williams \& Hatcher 1983), and high rates of loss of newly recruited fishes (Doherty \& Sale 1985, Victor 1986, Eckert 1987, Shulman \& Ogden 1987, Meekan 1988, Sale \& Ferrell 1988) are beginning to emerge as general patterns for these communities. While some studies have provided only circumstantial evidence (sensu Hixon 1991) of the effects of predation, experimental studies also support the idea that predation is important in determining local patterns of coexistence in reef-fish communities. For instance, the timing of recruitment of 2 species of piscivorous fishes has been shown to affect rates of settlement and/or survival of 2 other species of coral-reef fishes (Shulman et al. 1983). Predation has also been found to reduce the survivorship of juveniles of some sedentary, solitary species (Doherty \& Sale 1985) and to cause patterns of species richness and abundance of resident populations to diverge from patterns established by settling larvae (Caley 1993, Caley \& St. John in press). Sweatman (1984) estimated from direct observations of piscivory that newly recruited fishes can face a $65 \%$ annual chance of predation from a single species of lizardfish (Synodus englemani). As well, a negative correlation between the number of resident piscivores and the abundance of small prey fishes has been reported (Hixon \& Beets 1989, 1993) and the effects of quantity, quality and type of refuge from predation on community structure have all been demonstrated (Hixon \& Beets 1993, Caley \& St. John in press).

This study provides further evidence of the importance of predation in affecting the structure and dynamics of reef-fish communities. Interlocational patterns of predator recruitment were the same as the interlocational patterns of recruitment of all species considered together. The location with higher overall rates of recruitment, i.e. Lizard Island, also had the greater number of recruiting piscivores. This pattern of greater predator abundance at Lizard Island was maintained following recruitment. Patterns of species richness and abundance for residents of all species, however, were reversed at the 2 locations relative to their patterns of recruitment. That is, reefs at the location with greater recruitment, i.e. Lizard Island, ended up with fewer species of resident fishes and fewer 
individuals than reefs at One Tree Island. The reefs at Lizard Island also had more predators. Therefore, changes in patterns of species richness and abundance following recruitment at these 2 locations were consistent with an effect of predation that varied on a large spatial scale. In spite of having relatively few estimates of predator abundance over a time when predator numbers could fluctuate markedly due to pulses of recruitment (author's pers. obs.), mean predator abundance accounted for more than half the variation in the decline in abundance of residents of all species of fishes. Therefore, predators appear to have been able to override local patterns of recruitment in establishing local patterns of coexistence and differences in these patterns between locations

The relationships between predator abundance and local patterns of total abundance described here might arise if predation influenced a broad cross-section of species within these communities. Alternatively, if a single species had dominated the reef-fish communities at Lizard Island and this species experienced disproportionate mortality what I have interpreted at the community level would be better interpreted at the population level. The patterns described here were evident across species. For instance, a variety of species at both locations were present in large numbers (Table 1). Indeed, the 2 most abundant species were present at One Tree Island. These patterns suggest, then, that disproportionate losses of a single species at Lizard Island would have been unlikely to cause the differences observed in the patterns of abundance of recruits and residents at these 2 locations. Furthermore, patterns of species richness of recruits and residents were also reversed at the 2 locations. Therefore, the patterns described here appear to be community wide.

Because of the correlative nature of the data presented here, a causal relationship between regional variation in predator abundance and local, community-wide patterns of species richness and abundance cannot be claimed, nor can evidence of a direct relationship between predator abundance and local patterns of coexistence. For instance, the effects of predators on prey communities may interact with the abundance of prey through competitive interactions among prey and/or shelter availability of the habitats occupied (Hixon \& Beets 1989, 1993, Hixon \& Menge 1991, Caley \& St. John in press). Therefore, while the data presented in this paper are strongly suggestive of the effects of variation in predator abundance on patterns of coexistence of reef fishes, a definitive test of these effects will require manipulation of both recruitment rates and predator abundance.

The estimates of recruitment rates that I have reported here were based on relatively few censuses in only 1 year Therefore, pulses of recruitment may have been missed. If such recruitment events were missed at One Tree Island my interpretation here of regional differences in recruitment could be wrong. Recruitment data for the second year at both locations and a third year at One Tree Island alone, however, were all consistent with the patterns of recruitment reported here; average rates of recruitment at One Tree Island never exceeded those at Lizard Island (Caley 1991). Furthermore, recruitment rates of both Pomacentrus amboinensis and $P$. nagasakiensis have been reported elsewhere to be greater at Lizard Island than at One Tree Island (Sweatman 1985). Therefore, the interlocational differences in recruitment rates that I have reported here appear to be quite robust.

During this experiment, I only counted piscivorous fishes that either recruited to, or were resident on, these reefs. No attempts were made to assess the species richness or abundance of invertebrate piscivores such as stomatopods and cephalopods on these reefs. Also, the influence of transient, piscivorous fishes was not assessed. Predation from this latter source, however, appears to have been more common on the reefs at Lizard Island than on the reefs at One Tree Island (pers. obs.). For instance, on a number of occasions during censuses at Lizard Island only, large schools of trevally (Carangidae) swam quickly over the tops of these reefs. The approach of these trevally was always signaled by the rapid retreat of resident fishes into the interstices of reefs. I never observed successful predation at these times, but the immediate seeking of shelter by fishes inhabiting these reefs suggests that the trevally were perceived as a threat. Therefore, total predator abundance and differences in predation between locations are likely to have been underestimated in this study.

Interlocational differences in predator abundance can result from different processes. For instance, either species richness of piscivores relative to non-piscivores or intraspecific abundances of piscivores may vary. In this study, the species richness of predators relative to non-predators did not differ between locations. There were, however, differences in the abundance of piscivores at these 2 locations and in the taxonomic composition of these piscivore communities. The numerically dominant species of piscivores that settled on the reefs at Lizard Island were schooling species of snapper (Lutjanidae) or species of grouper (Serranidae) that recruited in greater numbers than confamilial species that settled at One Tree Island (Table 1). Therefore, the greater number of piscivores on the reefs at Lizard Island was the result of differences in the demography of the species of predators that recruited to these reefs as opposed to greater numbers of species of predators recruiting. 


\section{CONCLUSIONS}

This study supports the notion that interactions of ecological processes at large spatial scales can influence the structure and dynamics of biotic communities at a local scale. It also suggests that greater understanding of how local patterns of coexistence are determined will require knowledge of how regional species pools have evolved and how the composition of these pools and regional variation in the demographies of the species they include affect local community dynamics. While only interlocational differences in predation have been addressed here, it seems likely that other ecological processes may vary regionally and thereby influence the outcome of local ecological interactions.

Acknowledgements. S. Barrie, L. Goggin, O. Hoegh-Guldberg, J. MacGrory and T. Pople helped build the reefs used in this experiment. A. Gill and D. Hoese assisted with species identifications. Comments by R. A. Alford, J. Caselle, W. E. Neill, R. E. Ricklefs, D. Schluter, L. Schwarzkopf, A. R. E. Sinclair, D. Ward. R. R. Warner, J. A. Wiens and anonymous reviewers helped improve this manuscript. The Australian Geographic Society, the Australian Research Council, the Isaak Walton Killam Memorial Fund, the Natural Sciences and Engineering Research Council of Canada, the Royal Zoological Society of New South Wales, the University of Sydney, and the Australian Museum, through a Lizard Island Doctoral Fellowship, supported this research. This paper is a contribution from the Australian Museum's Lizard Island Field Station and the University of Sydney's One Tree Island Field Station and is contribution number 402 of James Cook University Department of Marine Biology.

\section{LITERATURE CITED}

Allen GR (1975) Damselfishes of the south seas. TFH Publ, Neptune City, NJ

Caley MJ (1991) Mechanisms of coexistence in communities of coral-reef fishes. PhD thesis, University of Sydney

Caley MJ (1993) Predation, recruitment and the dynamics of communities of coral-reef fishes. Mar Biol 117:33-43

Caley MJ, St. John J (in press) Refuge availability structures assemblages of tropical reef fishes. $J$ Anim Ecol

Cody ML (1993) Bird diversity components within and between habitats in Australia. In: Ricklefs RE, Schluter D (eds) Species diversity in ecological communities. University of Chicago Press, Chicago, p 147-158

Cornell HV (1993) Unsaturated patterns in species assemblages: the role of regional processes in setting local species richness. In: Ricklefs RE, Schluter D (eds) Species diversity in ecological communities. University of Chicago Press, Chicago, p 243-252

Cornell HV, Lawton JH (1992) Species interactions, local and regional processes, and limits to the richness of ecological communities: a theoretical perspective. J Anim Ecol 61: $1-12$

Doherty PJ (1991) Spatial and temporal patterns in recruitment. In: Sale PF (ed) The ecology of fishes on coral reefs. Academic Press, San Diego, p 261-293
Doherty PJ, Sale PF (1985) Predation on juvenile coral reef fishes: an exclusion experiment. Coral Reefs 4:225-234

Eckert GJ (1987) Estimates of aduIt and juvenile mortality for labrid fishes at One Tree Reef, Great Barrier Reef. Mar Biol 95:167-171

Emery AR (1978) The basis of fish community structure: marine and freshwater comparisons. Environ Biol Fish 3: $33-47$

Goldman B, Talbot FH (1976) Aspects of the ecology of coral reef fishes. In: Jones AO, Endean R (eds) Biology and geology of coral reefs, Vol 3, Biology 2. Academic Press, New York, p 125-154

Hiatt RW, Strasburg DW (1960) Ecological relationships of the fish fauna on coral reefs of the Marshall Islands. Ecol Monogr 30:65-127

Hixon MA (1991) Predation as a process structuring coralreef fish communities. In: Sale PF (ed) The ecology of fishes on coral reefs. Academic Press, San Diego, p $475-508$

Hixon MA, Beets JP (1989) Shelter characteristics and Caribbean fish assemblages: experiments with artificial reefs. Bull mar Sci 44:666-680

Hixon MA, Beets JP (1993) Predation, prey refuges, and the structure of coral-reef fish assemblages. Ecol Monogr 63: $77-101$

Hixon MA, Menge BA (1991) Species diversity: prey refuges modify the interactive effects of predation and competition. Theor Populat Biol 39:178-200

Jones GP (1991) Post-recruitment processes in the ecology of coral reef fish populations: a multifactorial perspective. In: Sale PF (ed) The ecology of fishes on coral reefs. Academic Press, San Diego, p 294-328

Meekan MG (1988) Settlement and mortality patterns of Juvenile reef fishes at Lizard Island Northern Great Barrier Reef. Proc 6th Int Coral Reef Symp 2:779-784

Myers RF (1989) Micronesian reef fishes. Coral Graphics, Agana, Guam

Randall JE, Allen GR, Steene RC (1990) Complete diver's and fisherman's guide to fishes of the Great Barrier Reef and the Coral Sea. Crawford House Press, Bathurst

Ricklefs RE (1987) Community diversity: relative roles of local and regional processes. Science 235:167-171

Russell BC (1983) Annotated checklist of the coral reef fishes in the Capricorn-Bunker Group, Great Barrier Reef Australia. Great Barrier Reef Marine Park Authority, Townsville

Sale PF, Ferrell DJ (1988) Early survivorship of juvenile coral reef fishes. Coral Reefs $7: 117-124$

Schluter D, Ricklefs RE (1993) Convergence and the regional component of species diversity. In: Ricklefs RE, Schluter D (eds) Species diversity and ecological communities. University of Chicago Press, Chicago, p 230-240

Shulman MJ, Ogden JC (1987) What controls tropical reef fish populations: recruitment or benthic mortality? An example in the Caribbean reef fish Haemulon flavolineatum. Mar Ecol Prog Ser 39:233-242

Shulman MJ, Ogden JC, Ebersole JP, McFarland WN, Miller SL, Wolf NG (1983) Prionty effects in the recruitment of juvenile coral reef fishes. Ecology 64:1508-1513

Sih A, Crowley P, McPeek M, Petranka J, Strohmeier K (1985) Predation, competition, and prey communjties: a review of field experiments. A Rev Ecol Syst 16:269-311

Sokal RR, Rohlf FJ (1981) Biometry. WH Freeman and Co, New York

Springer VG (1982) Pacific plate biogeography, with special reference to shore fishes. Smithson Contr Zool 367. $1-182$ 
Sweatman HPA (1984) A field study of the predatory behaviour and feeding rate of a piscivorous coral reef fish, the lizardfish Synodus englemani. Copeia 1984:187-193

Sweatman HPA (1985) The influence of adults of some coral reef fishes on larval recruitment. Ecol Monogr 55: $469-485$

Sweatman HPA (1993) Tropical snapper (Lutjanidae) that is piscivorous at settlement. Copeia 1993:1137-1139

Thresher RE (1991) Geographic variability in the ecology of coral reef fishes: evidence, evolution and possible implications. In: Sale PF (ed) The ecology of fishes on coral reefs. Academic Press, San Diego, p 401-436

This article was submitted to the editor
Victor BC (1986) Larval settlement and juvenile mortality in a recruitment-limited coral reef fish population. Ecol Monogr 56:145-160

Westoby M (1993) Biodiversity in Australia compared with other continents. In: Ricklefs RE, Schluter D (eds) Species diversity in ecological communities. University of Chicago Press, Chicago, p 170-177

Williams DMcB, Hatcher AI (1983). Structure of fish communities on outer slopes of inshore, mid-shelf and outer shelf reefs of the Great Barrier Reef. Mar Ecol Prog Ser 10:239-250

Winer BJ (1971) Statistical principles in experimental design McGraw-Hill Kogakusha, Tokyo

Manuscript first received: February 3, 1995

Revised version accepted: June 28, 1995 